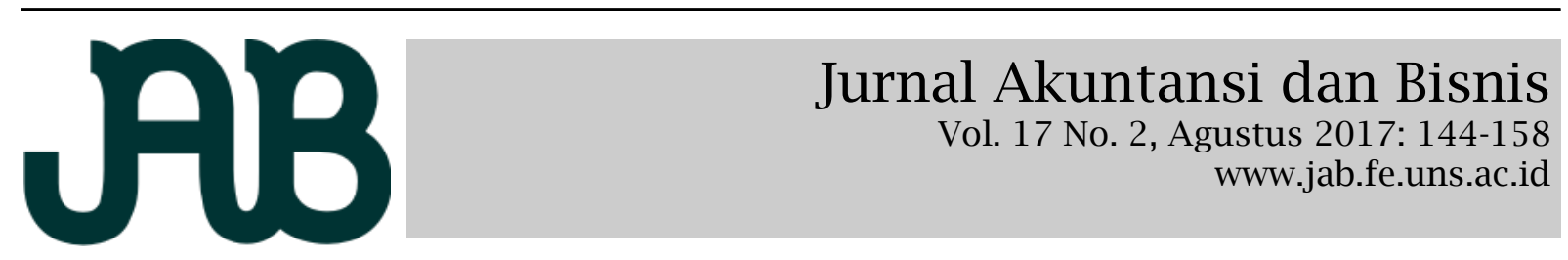

\title{
PENGARUH TUNTUTAN BERSIKAP ETIS DAN FAKTOR-FAKTOR PERSONAL TERHADAP PERILAKU AUDITOR PEMERINTAH DAERAH DALAM MENGHADAPI TEKANAN KERJA
}

\author{
YOHANSAH HANDOYO SETYAWAN (yohan_handoyo@yahoo.com) \\ Y ANNI ARYANI (y_anniaryani@staff.uns.ac.id)
}

Program Studi Magister Akuntansi, Fakultas Ekonomi dan Bisnis, Universitas Sebelas Maret, Indonesia

\begin{abstract}
A B S T R A C T
This study examines the effect of the interaction of personal factors and the demands being ethical on the behavior of Local Government Auditors when faced with working pressures. Personal factors in this study include: education, work experience, locus of control, and self-efficacy. This study employs Moderated Regression Analisys (MRA). Using 147 samples, we found that only the interaction of education and the demands of being ethical and interaction of work experience and the demands of being ethical that have significantly influence the behavior of the local government auditor when faced with working pressures. These results indicate that the strengthening of education and work experience which supported by consistent implementation of the standards of professional ethics by the agency may encourage the improvement of audit quality that is expected to be a product of Government Internal Supervisory Apparatus (APIP).

Keywords : ethical attitudes, personal factors, behavior, work pressure.

Penelitian ini menguji pengaruh interaksi tuntutan etis dan berbagai faktor personal terhadap perilaku auditor pemerintah daerah dalam menghadapi tekanan kerja. Faktor personal yang diteliti meliputi pendidikan, pengalaman kerja, locus of control dan self-efficacy. Penelitian ini menggunakan Moderated Regression Analysis (MRA). Menggunakan 147 sampel, kami menemukan bahwa hanya interaksi pendidikan dan tuntutan bersikap etis serta interaksi pengalaman kerja dan tuntutan bersikap etis yang berpengaruh positif signifikan terhadap perilaku auditor pemerintah daerah dalam menghadapi tekanan kerja. Hasil ini mengindikasikan bahwa penguatan pendidikan dan pengalaman kerja dengan didorong dengan implementasi standar etika profesi yang konsisten oleh instansi akan dapat meningkatkan kualitas audit yang sangat diharapkan menjadi produk dari Aparat Pengawasan Internal Pemerintah (APIP).

Kata kunci : perilaku etis, faktor personal, perilaku, tekanan kerja.
\end{abstract}

\section{PENDAHULUAN}

Auditor pemerintah daerah adalah pelaksana tugas pokok dan fungsi Aparat Pengawasan Internal Pemerintah (APIP). Undang-undang No. 32 Tahun 2004 mengamanatkan kepada APIP untuk melaksanakan kegiatan pengawasan atas pelaksanaan urusan pemerintahan di daerah, peraturan daerah, dan peraturan kepala daerah. Intensitas kegiatan pengawasan yang tinggi tersebut menimbulkan tekanan kerja bagi auditor. Tekanan kerja, sebagaimana dikemukakan oleh Lord dan DeZoort (2001), Umar dan Anandarajan (2004), Acevedo (2007), Robertson (2007), serta Yuen, Law, Lu, dan Quan (2010), mengakibatkan kurangnya kualitas hasil audit. Secara nasional, terkait dengan kualitas hasil auditnya, peran Inspektorat Daerah pun dipertanyakan, dimana sesuai data Kementerian Dalam Negeri sepanjang kurun 2009-2014 sebanyak 318 Kepala Daerah/Wakil Kepala Daerah tersangkut korupsi (Wiwoho, 2015).

Pencapaian kinerja auditor diyakini mendapatkan pengaruh dari cara menyikapi tekanan kerja. Penting bagi auditor untuk mengelola potensi diri mereka karena faktor personal berperan penting dalam penyelesaian suatu masalah. Beberapa potensi diri atau faktor personal yang terkait dengan pelaksanaan tugas auditor diantaranya: pendidikan (Rai, 2008; Iskandar, Sari, Sanusi, \& Anugerah, 2012; 
Setyaningrum, 2012), pengalaman kerja (O'Leary\& Stewart, 2007; Peytcheva \& Gillet, 2012; Iskandar et al., 2012), locus of control (Paino, Ismail, \& Smith, 2011; Donnelly, Quirin, \& O'Bryan, 2003; Peytcheva \& Gillet, 2012), serta self efficacy (Handayani, 2008; Yuen et al., 2010; Iskandar et al., 2012).

Sikap etis seorang auditor termasuk dalam kategori gaya kognitif (cognitive style) dimana cognitive style merujuk pada cara atau metode dimana individu menerima, menyimpan, memproses, dan mengirimkan informasi (Puspitaningtyas, 2007). Disebutkan oleh Purnamasari, Rohman, dan Chariri (2014) bahwa pengambilan keputusan oleh seseorang dapat dipengaruhi oleh interaksi variabel personal dengan gaya kognitif. Ikhsan (2008) menyatakan bahwa pengembangan strategi untuk memotivasi dan mempengaruhi perilaku adalah salah satu ruang lingkup dalam akuntansi keperilakuan.

Beberapa penelitian telah mengulas interaksi faktor-faktor personal dan etika yang dikaitkan dengan perilaku auditor, diantaranya adalah penelitian yang dilakukan oleh Shafer, Morris, dan Ketchand (2001), Chan dan Leung (2006), Pratiwi dan Suwardi (2007), Hidayat dan Handayani (2010), Setyaningrum (2012), Ghazali dan Ismail (2013), serta Shahri, Abdoli, dan Rahmani (2013). Berbagai penelitian tersebut masih menghasilkan kesimpulan yang tidak konsisten. Peran Inspektorat Daerah yang masih dipertanyakan dalam menghasilkan hasil audit yang berkualitas dan bervariasinya hasil penelitian terdahulu memotivasi dilakukannya penelitian untuk menguji pengaruh tuntutan bersikap etis dan faktor-faktor personal terhadap perilaku Auditor Pemerintah Daerah dalam menghadapi tekanan kerja.

Paper ini diorganisasi sebagai berikut. Bagian berikutnya merupakan tinjauan pustakan dan pengembangan hipotesis. Bagian selanjutnya adalah metode penelitian yang dilanjutkan dengan analisis dan pembahasan. Bagian terakhir merupakan simpulan, keterbatasan dan saran.

\section{TIN JAUAN PUSTAKAN DAN PENGEMBANGAN HIPOTESIS Teori Atribusi}

Teori atribusi adalah teori yang menjelaskan penyebab perilaku orang lain atau diri sendiri (Luthans, 2006). Teori atribusi memberikan pengertian ke dalam proses sehingga dapat diketahui sebab dan motif perilaku seseorang (Gibson, Ivancevich, \& Donnelly, 2000), menguji faktor penentu perilaku (Cort, Griffith, \& White, 2007), serta mengembangkan penjelasan mengenai cara penilaian terhadap seseorang secara berlainan, tergantung dari suatu makna yang diatribusikan/ dihubungkan ke suatu perilaku tertentu (Robbins, 2003). Teori atribusi berhubungan dengan proses kognitif dimana seseorang mengintepretasikan perilaku berhubungan dengan bagian tertentu dari lingkungan yang relevan.

Berdasarkan uraian mengenai teori atribusi tersebut, disimpulkan bahwa teori atribusi dapat digunakan untuk mengetahui pengaruh tuntutan bersikap etis dan faktor-faktor personal terhadap perilaku auditor pemerintah daerah dalam menghadapi tekanan kerja. Pengetahuan mengenai pengaruh tuntutan bersikap etis yang diinteraksikan dengan faktor-faktor personal terhadap perilaku auditor pemerintah daerah dalam menghadapi tekanan kerja dapat menjadi bahan evaluasi atas pelaksanaan tugas-tugas pengawasan internal oleh Aparat Pengawasan Internal Pemerintah (APIP).

\section{Auditor Pemerintah Daerah}

Fungsi audit intern pemerintah dilaksanakan oleh lembaga-lembaga yang tergabung dalam Aparat Pengawasan Internal Pemerintah (APIP) yang meliputi Badan Pengawasan Keuangan dan Pembangunan (BPKP), Inspektorat Jenderal Kementerian/Lembaga, serta Inspektorat Daerah. Auditor adalah seseorang dengan kualifikasi tertentu untuk melaksanakan audit atas laporan keuangan dan kegiatan suatu entitas. Sesuai Anggaran Dasar/ Anggaran Rumah Tangga Asosiasi Auditor Intern Pemerintah Indonesia (AAIPI) disebutkan bahwa pengertian auditor mencakup Pejabat Fungsional Auditor (PFA) 
dan Pengawas Penyelenggaraan Urusan Pemerintahan di Daerah (P2UPD) yang berkedudukan sebagai pelaksana teknis fungsional di bidang pengawasan di lingkungan APIP.

Sebagaimana fungsi audit internal yang dikemukakan oleh Gramling dan Hermanson (2006), auditor pemerintah daerah dapat berkontribusi terhadap tata kelola dengan memberikan pelayanan berupa pemberian informasi, jaminan, saran, dan keahlian. Schneider (2003) mengemukakan bahwa fungsi audit internal yang berfokus pada masalah keuangan dapat meningkatkan kualitas pelaporan keuangan. Audit internal juga meliputi pengendalian resiko (Carpenter \& Mahoney, 2010), sehingga dibutuhkan kredibilitas yang meliputi kompetensi, obyektivitas, dan kepercayaan (Comunale \& Sexton, 2004).

\section{Perilaku}

Perilaku adalah semua yang dilakukan seseorang, meliputi pergerakan, observasi, berkomunikasi, proses berfikir, dan pemecahan masalah (Gibson et al., 2000), berupa sikap, tindakan, atau tingkah laku (Wursanto, 2005). Robbin dan Judge (2008) menjelaskan bahwa perilaku adalah salah satu komponen sikap selain kesadaran dan perasaan, dimana sikap adalah pernyataan evaluatif terhadap obyek, individu, atau peristiwa. Perilaku seseorang didorong oleh pengaruh internal (dalam diri orang tersebut) dan pengaruh eksternal (tekanan lingkungan).

Profesi auditor pemerintah daerah terikat oleh prinsip-prinsip perilaku yaitu integritas, obyektivitas, pengetahuan, keahlian, pengalaman, dan ketrampilan yang diperlukan untuk melaksanakan tugas, akuntabel, dan profesional, serta aturan-aturan perilaku sebagaimana termuat dalam Peraturan Menteri Pendayagunaan Aparatur Negara Nomor PER/04/ M.PAM/03/2008 dan Kode Etik Auditor Intern Pemerintah Indonesia. Aturan perilaku dalam ketentuan mengenai kode etik meliputi hal-hal yang terkait dengan sikap dalam bekerja yang menekankan kejujuran, ketekunan, dan bertanggungjawab, taat hukum, hormat dan berkontribusi pada tujuan organisasi, serta tidak menerima gratifikasi. Yuen et al. (2010) menerangkan bahwa perilaku auditor disfungsional secara signifikan mempengaruhi kualitas audit.

\section{Tekanan Kerja}

Tekanan kerja mengacu kepada kesadaran atau perasaan disfungsi pribadi sebagai akibat kondisi atau kejadian yang dirasakan di tempat kerja, juga reaksi psikologis dan fisiologis yang disebabkan situasi yang dirasa tidak nyaman, tidak diinginkan, atau ancaman langsung di lingkungan tempat kerja (Chen, Silverthorne, \& Hung, 2006). Dampak atau bukti seseorang merasakan tekanan kerja adalah menurunnya komitmen dan produktivitas. Tuntutan lingkungan yang sering menekan seorang auditor internal untuk berperilaku disfungsional antara lain: tekanan untuk mengikuti kemauan manajemen atau auditan (Umar \& Anandarajan, 2004; Hidayat \& Handayani, 2010), tekanan tenggat waktu penyelesaian tugas (Robertson, 2007; Svanberg \& Ohman, 2012), serta tekanan kompleksitas tugas (Tan, Ng, \& Mak, 2002; Sanusi \& Iskandar, 2007).

Tekanan dari manajemen/atasan maupun dari auditan berpengaruh terhadap judgement auditor. Teori ketaatan menyatakan bahwa kekuasaan dapat dimanfaatkan individu sebagai sumber yang dapat mempengaruhi perilaku orang lain melalui perintah yang diberikan dengan keberadaan kekuasaan atau otoritas sebagai bentuk dari legitimate power (Jamilah, Fanani, \& Chandrarin 2007). Menghadapi tekanan tenggat waktu penyelesaian tugas, auditor dapat bereaksi secara disfungsional (Svanberg \& Ohman, 2012). Kompleksitas tugas menurut Sanusi \& Iskandar (2007) adalah suatu fungsi dari tiga dimensi tugas itu sendiri: banyaknya komponen dan informasi yang diperlukan untuk menyelesaikan tugas, kesukaran pada hal-hal dalam hubungan antara informasi, tindakan, dan produk, serta keberadaan hal-hal yang sukar tersebut stabil sepanjang waktu

\section{Tuntutan Bersikap Etis}

Etika berkaitan dengan pertanyaan bagaimana orang akan berperilaku ter- 
hadap sesamanya (Kell, Johnson, \& Boynton, 2002). Auditor pemerintah daerah adalah sebuah profesi yang tunduk kepada kode etiknya untuk dapat bersikap etis. Berdasarkan Peraturan Pemerintah Nomor 40 Tahun 2010 ditetapkan bahwa etika profesi bagi jabatan fungsional keahlian dan jabatan fungsional ketrampilan ditetapkan oleh organisasi profesi. Saat ini Asosiasi Auditor Intern Pemerintah (AAIPI) telah menetapkan kode etik dalam profesi Auditor Intern Pemerintah yang terdiri atas 2 (dua) komponen dasar yaitu prinsip etika yang relevan dengan profesi dan praktik pengawasan intern pemerintah serta aturan perilaku yang menggambarkan norma perilaku yang diharapkan bagi auditor intern pemerintah dalam memenuhi tanggung jawab profesionalnya.

Peterson (2003) mendefinisikan tekanan etis sebagai tekanan untuk terlibat dalam aktivitas pekerjaan yang tidak etis, sehingga tuntutan bersikap etis adalah tuntutan untuk tetap berperilaku sesuai etika profesi berkaitan dengan adanya tekanan untuk terlibat dalam aktivitas pekerjaan yang tidak etis. Penelitian oleh O'Leary dan Steward (2007) mendapatkan temuan bahwa auditor internal sensitif terhadap dilema etika tetapi tidak selalu yakin bahwa rekan-rekannya akan bertindak secara etis. Banyak faktor yang ketika berinteraksi dengan tuntutan bersikap etis akan mempengaruhi perilaku seorang audi- tor. Beberapa faktor tersebut yang diuji dalam penelitian ini adalah faktor pendidikan, pengalaman kerja, locus of control, dan self-efficacy. Secara ringkas, kerangka berfikir dalam penelitian ini disajikan dalam Gambar 1.

\section{Pendidikan}

Pendidikan dalam konteks profesi tidak hanya berupa jalur dan jenjang pendidikan formal namun termasuk juga pendidikan profesi berkelanjutan. PerMenPAN No. 220/ M.PAN/7/2008 dan Peraturan Menteri Dalam Negeri No. 47 Tahun 2010 menyiratkan keharusan tercakupnya pendidikan formal dan pendidikan keprofesian tersebut. Pierce dan Sweeney (2000) menemukan bahwa tingkat pendidikan berhubungan secara signifikan dengan penerimaan terhadap budaya etis. Demikian juga Kum-Lung dan Teck-Chai (2010) yang menemukan bukti bahwa individu dengan tingkat pendidikan yang lebih tinggi cenderung untuk lebih bersikap etis. Pendidikan memberikan bekal yang membantu individu untuk memutuskan perilaku apa yang bisa diterima dan apa yang tidak. Standar etika individu akan berbeda tergantung dari tingkat pendidikannya (Keller, Smith, \& Smith, 2007). Menurut Yoo dan Donthu (2002), tidak hanya pendidikan jalur dan jenjang pendidikan formal yang menentukan perilaku etis.

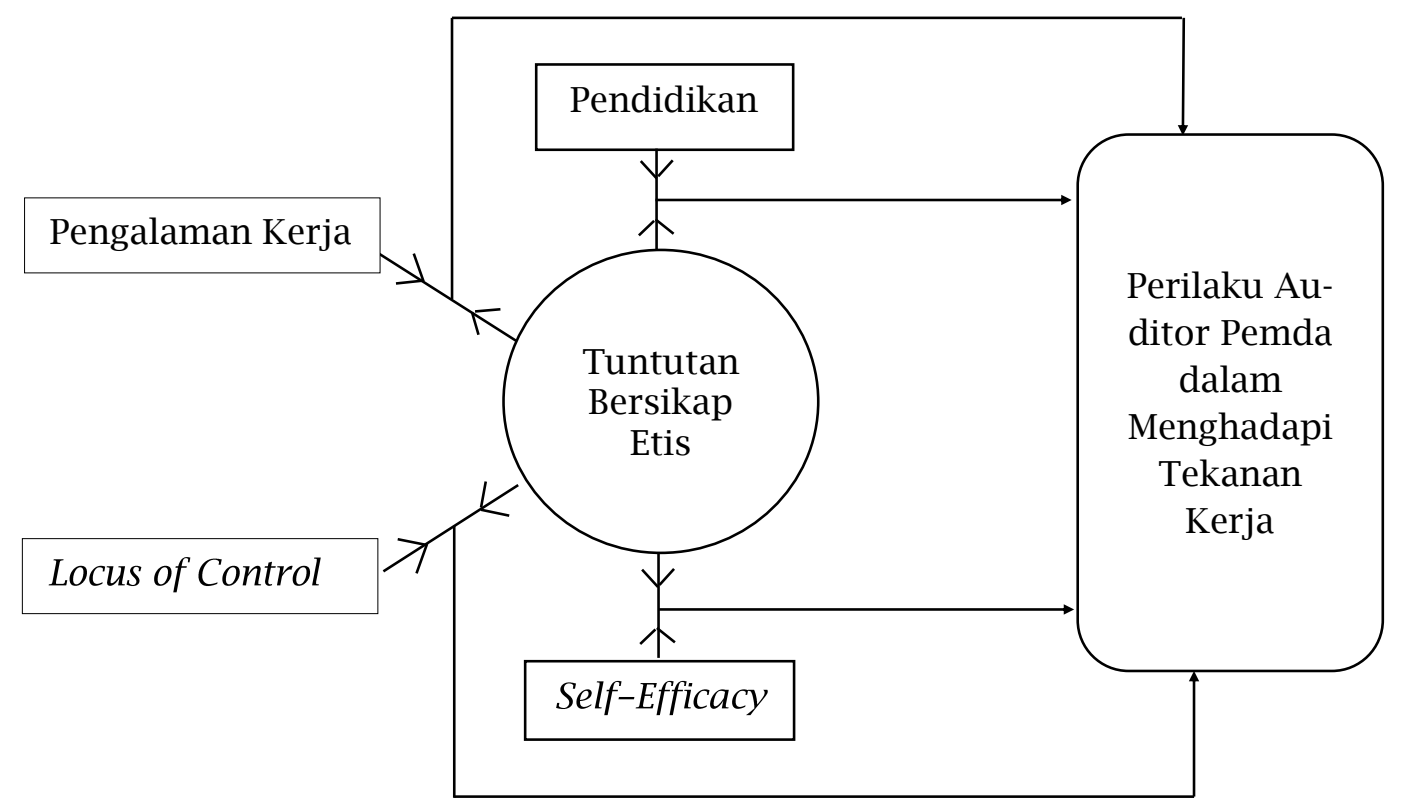

Gambar 1.

Model Kerangka Berfikir 


\section{Interaksi Pendidikan dan Tuntutan Bersikap Etis}

Kekayaan pengetahuan sangat mendukung pelaksanaan tugas audit (Iskandar et al., 2012). Sesuai standar audit dan kode etik profesi, auditor pemerintah daerah dituntut untuk memiliki kompetensi yang memadai. Latar belakang dan jenjang pendidikan serta pelatihan teknis yang terkait profesi berperan penting bagi auditor dalam memberikan laporan audit yang lebih baik (Setyaningrum, 2012). Tingkat pendidikan berhubungan dengan penerimaan terhadap budaya etis dan kecenderungan sikap etis seseorang (Pierce \& Sweeney, 2000; Kum-Lung \& Teck-Chai, 2010).

Meskipun Keller et al. (2007) menyatakan bahwa pendidikan adalah faktor penting terkait tindakan etis yang diharapkan, namun beberapa peneliti menemukan bahwa faktor personal saja tidak dapat mempengaruhi perilaku, diantaranya adalah Nather (2013), Shafer et al. (2001), dan juga Pratiwi dan Suwardi (2007) yang kemudian menginteraksikan faktor personal dengan pertimbangan etis. Hal tersebut sesuai pendapat Chan dan Leung (2006) bahwa sensitivitas etika tidak berpengaruh terhadap pertimbangan etis, sehingga intervensi etika oleh instansi penting dalam membuat auditor lebih mempertimbangkan etika dalam perilakunya. Argumen tersebut disusun dalam hipotesis berikut.

H1 : Interaksi pendidikan dan tuntutan bersikap etis berpengaruh positif terhadap perilaku auditor dalam menghadapi tekanan kerja

\section{Pengalaman Kerja}

Salah satu faktor individual penting dalam profesi dan pelaksanaan tugas seorang auditor adalah pengalaman (O'Leary \& Stewart, 2007). Pengalaman kerja mengacu pada lamanya seseorang menjalankan tugas atau berprofesi sebagai auditor. Pengalaman kerja juga ditunjukkan dengan jenis-jenis pekerjaan yang pernah dilakukan yang dengan itu akan tercipta peluang yang lebih besar bagi seseorang untuk dapat melakukan suatu pekerjaan atau tugas dengan lebih baik. Johnstone Bedard, dan
Biggs (2002) menemukan bahwa auditor yang lebih berpengalaman bekerja lebih baik karena mereka memiliki dasar pengetahuan yang lebih besar lebih mahir mengorganisir pengetahuan mereka tersebut. Besarnya pengalaman bermanfaat bagi pengembangan keahlian dan akan mempengaruhi dalam pelaksanakan tugasnya. Herliansyah dan Ilyas (2006) telah menunjukkan bukti bahwa pengalaman seorang auditor akan mengurangi dampak informasi tidak relevan dalam auditor membuat judgement. Christiawan (2002) juga telah memberikan bukti bahwa pengalaman memiliki pengaruh yang positif terhadap kualitas audit yang dihasilkan oleh seorang auditor.

\section{Interaksi Pengalaman Kerja dan Tuntutan Bersikap Etis}

Pengalaman kerja auditor memberikan dampak positif untuk pengorganisasian pengetahuannya (Johnstone et al., 2002; O'Leary \& Stewart, 2007), mengurangi dampak informasi tidak relevan dalam pembuatan judgement (Herliansyah \& Ilyas, 2006), serta menjadikan auditor lebih mampu menghasilkan laporan audit yang lebih berkualitas (Christiawan, 2002). Pengalaman kerja yang bertambah akan meningkatkan penerimaan terhadap budaya etis (Pierce \& Sweeney, 2000), meningkatkan standar etika individu (Keller et al., 2007), serta menjadikan auditor lebih siap menghadapi dilema etika yaitu menolak berperilaku disfungsional (Ghazali \& Ismail, 2013).

Mendapatkan tuntutan untuk bersikap etis, pengalaman seorang auditor diuji apakah semakin berintegritas, obyektif, kompeten, dan profesional, ataukah sebaliknya. Hidayat dan Handayani (2010) menemukan tidak adanya pengaruh interaksi pengalaman kerja dan pertimbangan etis terhadap perilaku auditor. Hal tersebut dimungkinkan terjadi mengingat bahwa sensitivitas etika tidak berpengaruh terhadap pertimbangan etis, sehingga intervensi etika oleh instansi penting dalam membuat auditor lebih mempertimbangkan etika dalam perilakunya (Chan \& Leung, 2006). Argumen tersebut disusun dalam hipotesis 
berikut.

H2 : Interaksi pengalaman kerja dan tuntutan bersikap etis berpengaruh positif terhadap perilaku auditor dalam menghadapi tekanan kerja

\section{Locus of Control}

Locus of control merupakan salah satu faktor individual yang mempengaruhi cara pandang seseorang terhadap suatu peristiwa, yaitu apakah dia dapat mengendalikan peristiwa tersebut atau tidak. Locus of control mengacu pada sejauhmana individu mengatribusi (menghubungkan) peristiwa dalam hidup mereka pada suatu tindakan atau kekuatan di luar kendali mereka (Nasution \& Ostermark, 2012). Individu mengembangkan ekspektasi atas sukses mereka dalam situasi tertentu bergantung pada perilaku pribadi mereka sendiri atau dikendalikan oleh kekuatan eksternal (Paino et al., 2011). Locus of control merupakan keyakinan bahwa seseorang dapat atau tidak dapat mengendalikan nasibnya sendiri atau perspektif seseorang apakah ia mampu mengontrol perilaku yang terjadi padanya (Dali \& Mas'ud, 2014).

\section{Interaksi Locus of Control dan Tuntutan Bersikap Etis}

Locus of control berpengaruh terhadap judgement auditor (Nasution \& Ostermark, 2012). Locus of control yang diinteraksikan dengan kesadaran etis berpengaruh terhadap perilaku auditor dalam kondisi dilema etis, yaitu bahwa hubungan antara locus of control dengan perilaku auditor dapat tergantung pada kesadaran etis auditor tersebut (Muawanah \& Indriantoro, 2001). Shapeero, Koh, dan Killough (2003) menerangkan bahwa ketika menghadapi tekanan kerja, auditor dengan locus of control internal cenderung taat pada tuntutan etika profesi, sedangkan auditor dengan locus of control eksternal menganggap diri mereka secara pribadi tidak bertanggungjawab atas konsekuensi dari perilaku yang tidak sesuai aturan atau tidak etis.

Tuntutan bersikap etis adalah kondisi ideal yang diharapkan ketika seorang auditor menghadapi atau mendapatkan tekanan untuk berbuat yang tidak sesuai standar etika profesinya. Locus of control seorang auditor akan diuji ketika mendapatkan tuntutan tersebut. Menurut Muawanah dan Indriantoro (2001) hubungan antara locus of control dengan perilaku auditor dapat tergantung pada kesadaran etisnya. Mengingat bahwa kesadaran etis atau sensitivitas etika sangat memerlukan intervensi etika oleh instansi (Chan \& Leung, 2006), maka locus of control seorang auditor yang didukung dengan tuntutan bersikap etis oleh instansi akan mendorong dan menempatkan pada sikap ideal yang diharapkan ketika menghadapi kondisi tekanan kerja yaitu lebih dapat menghadapinya dengan menjaga integritas, independensi, kompetensi, dan profesionalitas. Argumen tersebut disusun dalam hipotesis berikut.

H3 : Interaksi tuntutan bersikap etis dan locus of control berpengaruh terhadap perilaku auditor dalam menghadapi tekanan kerja

\section{Self-Efficacy}

Self-efficacy adalah keyakinan bahwa seseorang memiliki kapasitasnya untuk mengatur dan melaksanakan tindakan yang diperlukan untuk mendapatkan hasil yang diinginkan (Iskandar et al., 2012). Seseorang memiliki kemampuan untuk mengontrol pikiran, perasaan, dan tindakannya sendiri, sedangkan kemampuannya tersebut sangat dipengaruhi oleh persepsi atas dirinya sendiri. Self-efficacy dianggap menjadi penentu bagaimana individu merasakan, berfikir, memotivasi diri, dan berkelakuan. Individu dengan self-efficacy yang tinggi akan mencurahkan segenap usahanya untuk mencapai kinerja yang baik (Engko, 2006). Keyakinan diri merasa mampu akan menuntun seseorang pada usaha yang memadai untuk mencapai keberhasilan atas pekerjaan atau tugasnya tersebut. Self- efficacy hanya terkait dengan persepsi atau keyakinan seseorang saja dan bukanlah mengenai kemampuan yang sebenarnya (Hidayat \& Handayani, 2010).

Interaksi Tuntutan Bersikap Etis dan SelfEfficacy

Self-efficacy menentukan bagaimana seseorang merasakan, berpikir, memotivasi 
diri sendiri dan berkelakuan (Handayani, 2008) serta dianggap menjadi penentu bagaimana individu merasakan, berfikir, memotivasi diri, dan berkelakuan (Iskandar et al., 2012). Auditor dengan self-efficacy yang tinggi melakukan usaha yang lebih memadai untuk mencapai apa yang menjadi tujuannya. Namun demikian selfefficacy berhubungan dengan keyakinan dan bukan tentang kemampuan yang sebenarnya (Hidayat \& Handayani, 2010). Dengan demikian perkembangan keyakinan tersebut yaitu tumbuh ataukah berkurang tergantung kepada tingkat keberhasilan yang telah didapatkan pada pelaksanaan tugas-tugasnya. Persepsi atas prestasi dan kinerja masa lalu yang baik dan sikap atasan memiliki pengaruh yang besar terhadap self-efficacy dan prestasi kerja seorang auditor (Yuen et al., 2010). Sehubungan dengan hal tersebut, intervensi dari instansi melalui penginteraksian tuntutan bersikap etis pada self-efficacy menentukan bagaimana perilaku auditor ketika menghadapi tekanan kerja. Argumen tersebut disusun dalam hipotesis berikut.

H4 : Interaksi tuntutan bersikap etis dan self-efficacy berpengaruh positif terhadap perilaku auditor dalam menghadapi tekanan kerja.

\section{METODE PENELITIAN \\ Populasi dan Sampel}

Populasi dalam penelitian ini adalah auditor pemerintah pada Aparat Pengawasan Internal Pemerintah (APIP) atau instansi Inspektorat Kabupaten/Kota se-Provinsi Jawa Tengah. Sampel yang diambil untuk penelitian adalah auditor pemerintah daerah di wilayah eks Karesidenan Surakarta Jawa Tengah yang meliputi 6 Kabupaten dan 1 Kota, dengan kriteria adalah seluruh Pejabat Fungsional Auditor (PFA) dan Pengawas Penyelenggaraan Urusan Pemerintahan di Daerah (P2UPD) pada semua jenjang jabatan dan kedudukan dalam tim. Responden yang memenuhi sampel sejumlah 164.

\section{Cara Pengumpulan Sampel}

Sampel dikumpulkan dengan teknik purposive sampling. Data dalam penelitian ini menggunakan metode survei melalui kuesioner. Kuesioner dikirim langsung kepada responden karena jarak dan waktu yang masih dapat terjangkau.

\section{Strategi Penelitian}

Kuesioner dalam penelitian ini dikembangkan dari kuesioner yang telah dikembangkan dalam penelitian terdahulu (Jamilah et al., 2007; Svanberg \& Ohman, 2012; Reiss \& Mitra, 1998; Sanusi dan Iskandar, 2007; serta Shafer, 2002). Tidak semua pertanyaan dalam kuesioner pada penelitian-penelitian terdahulu tersebut dapat langsung digunakan, mengingat format pertanyaan yang tidak seragam dan bahasa yang cukup rumit pada literatur berbahasa asing, selain itu skala tanggapan yang akan digunakan untuk pengukuran juga bervariasi, 5 (lima) poin dan 7 (tujuh) poin.

Berkaitan dengan hal tersebut, dalam penelitian ini digunakan strategi sebagai berikut: (1) menyamakan format pertanyaan yaitu menjadi format pernyataan serta menyamakan skala tanggapan menjadi skala Likert 5 poin untuk semua variabel penelitian; (2) melakukan uji coba/pilot testing untuk mendapatkan tanggapan mengenai kuesioner yang meliputi kejelasan pertanyaan, bahasa yang digunakan, serta kecukupan pertanyaan/indikator; (3) memberikan pengantar singkat mengenai definisi variabel pada bagian awal kuesioner; (4) melakukan follow up sesegera mungkin untuk memastikan tingkat tanggapan yang memadai yaitu dengan mengambil kembali kuesioner maksimal 3 (tiga) hari setelah dikirim.

\section{Definisi Operasional dan Pengukuran Variabel}

Dalam penelitian ini yang dimaksud dengan auditor pemerintah daerah adalah pejabat fungsional pada Inspektorat Provinsi dan Inspektorat Kabupaten/Kota yang terdiri atas Pejabat Fungsional Auditor (PFA) dan Pengawas Penyelenggaraan Urusan Pemerintahan di Daerah (P2UPD). Sesuai permasalahan dan hipotesis maka dalam penelitian ini variabel yang akan dianalisis terdiri dari : (1) variabel dependen 
adalah perilaku Auditor Pemerintah Daerah dalam menghadapi tekanan kerja; (2) variabel independen adalah faktor-faktor personal yang meliputi pendidikan, pengalaman kerja, locus of control, dan selfefficacy, serta (3) variabel moderating adalah tuntutan bersikap etis.

Tekanan kerja muncul sebagai akibat tuntutan dalam lingkungan suatu profesi dimana untuk profesi auditor tekanan lingkungan yang berpotensi menciptakan perilaku disfungsional tersebut meliputi: tekanan untuk mengikuti kemauan manajemen dan auditan (Umar \& Anandarajan, 2004; Jamilah et al., 2007; Hidayat \& Handayani, 2010), tekanan tenggat waktu penyelesaian tugas (Robertson, 2007; Svanberg \& Ohman, 2012), serta tekanan kompleksitas tugas (Tan et al., 2002; Sanusi \& Iskandar, 2007; Jamilah et al., 2007). Bagaimana auditor pemerintah daerah bertingkah laku atau melakukan tindakan berupa gerakan, observasi, komunikasi, berfikir, dan memecahkan masalah, ketika menghadapi tekanan kerja dalah fokus penelitian ini.

Instrumen pengukuran perilaku auditor pemerintah daerah dalam menghadapi tekanan kerja :

1. Pengukuran perilaku auditor dalam menghadapi tekanan manajemen dan auditan adalah kuesioner yang dikembangkan oleh Jamilah et al. (2007) yang disesuaikan dan digunakan sebanyak 7 (tujuh) pernyataan untuk direspon, diukur dengan skala Likert lima poin, dimana indikator perilaku fungsional atau etis ketika menghadapi tekanan manajemen dan auditan adalah tetap bersikap profesional dengan melaksanakan tugas berpedoman pada Standar Audit APIP.

2. Pengukuran perilaku auditor dalam menghadapi tekanan tenggat waktu penyelesaian tugas adalah berupa kuesioner yang diadopsi dari Otley dan Pierce oleh Svanberg dan Ohman (2012) yang telah disesuaikan dan digunakan sebanyak 7 (tujuh) pernyataan untuk direspon, diukur dengan skala Likert lima poin, dimana indikator perilaku fungsional atau etis ketika menghadapi tekanan tenggat waktu penyelesaian tu- gas adalah kemampuan menyelesaikan dan melaporkan hasil audit sesuai alokasi waktu yang disediakan, mendapatkan penjelasan yang lengkap, melaksanakan reviu secara mendalam, cermat dan teliti, serta melalui semua langkah atau tahapan dalam prosedur audit.

3. Pengukuran perilaku auditor dalam menghadapi tekanan kompleksitas tugas adalah kuesioner yang dikembangkan oleh Jamilah et al. (2007) yang telah disesuaikan dan digunakan sebanyak 5 (lima) pernyataan untuk direspon, diukur dengan skala Likert lima poin, dimana indikator perilaku fungsional atau etis ketika menghadapi tekanan kompleksitas tugas adalah memahami dengan jelas setiap penugasan audit dan bagaimana menyelesaikannya.

Variabel pendidikan terdiri atas pendidikan formal serta pendidikan latihan keprofesian bersifat wajib dan pengembangan. Pendidikan formal dalam penelitian ini mencakup Diploma IV (DIV/ Sarjana (S1), Pendidikan Profesi Akuntan (PPA), Master (S2), dan Doktor (S3); pendidikan latihan keprofesian wajib meliputi Diklat Pembentukan Jabatan Fungsional (Anggota Tim), Diklat Ketua Tim, Diklat Pengendali Teknis, dan Diklat Pengendali Mutu; serta pelatihan pengembangan berupa Bimbingan Teknis, workshop, dan seminar. Informasi mengenai pendidikan diperoleh dari data demografik responden. Pengukuran variabel pendidikan dalam penelitian ini dilakukan dengan mengambil rerata hitung (mean atau average) dari skor ketiga unsur dalam variabel ini yaitu pendidikan formal, pendidikan latihan keprofesian wajib, dan pelatihan pengembangan.

Variabel pengalaman kerja ditetapkan dengan batasan masa kerja dalam profesi selama 4 (empat) tahun seperti yang digunakan oleh Tsui dan Gul dan diadopsi oleh Hidayat dan Handayani (2010). APIP/Inspektorat dengan Program Kerja Pengawasan Tahunan (PKPT) memungkinkan seorang auditor dengan pengalaman masa kerja profesi selama 4 (empat) tahun dianggap telah mampu menghadapi permasalahan-permasalahan dalam pelaksanaan tugas profesinya. Pengukuran 
variabel dalam penelitian ini yaitu auditor pemerintah daerah yang telah berpengalaman diberikan skor 1 sedangkan yang belum perpengalaman diberi skor 0. Informasi mengenai pengalaman kerja dalam profesi auditor diperoleh dari data demografik responden.

Variabel locus of control mengukur tingkat keyakinan seseorang atas apa yang terjadi dalam hidupnya. Penentuan locus of control menggunakan menggunakan kuesioner Reiss \& Mitra (1998) yang telah disesuaikan dan digunakan sebanyak 16 (enam belas) pernyataan untuk direspon, diukur dengan skala Likert 5 poin.

Self-efficacy adalah keyakinan yang dimiliki seseorang mengenai peluangnya dalam mencapai keberhasilan pelaksanaan suatu tugas. Instrumen untuk menentukan self-efficacy menggunakan 4 (empat) pernyataan yang dikembangkan oleh Sanusi et al. (2007) yang telah disesuaikan dan digunakan sebanyak 4 (empat) pernyataan untuk direspon, diukur dengan skala Likert 5 poin.

Tuntutan bersikap etis yaitu tuntutan untuk tetap berperilaku sesuai etika profesi sehubungan adanya tekanan untuk terlibat dalam aktivitas pekerjaan yang tidak etis, dioperasionalkan sebagai kemampuan seorang auditor pemerintah daerah mengevaluasi dan memilih untuk taat terhadap nilai-nilai etika dalam pelaksanaan tugas profesinya. Pengukuran tuntutan bersikap etis menggunakan instrumen yang diadopsi dari Shafer (2002) yang telah disesuaikan dan digunakan sebanyak 4 (empat) pernyataan untuk direspon, diukur dengan skala Likert 5 poin.

\section{Uji Analisis Data}

Penelitian ini menggunakan bantuan alat statistik software SPSS versi 17.0, baik untuk pengujian validitas dan reliabilitas kuesioner maupun dalam pengujian hipotesis penelitian. Sesuai yang dijelaskan oleh Sekaran dan Bougie (2012), maka sebelum data dianalisis, dilakukan proses editing, coding, dan screening. Dalam penelitian ini digunakan persamaan regresi melalui uji interaksi atau Moderated Regression Analysis (MRA). MRA merupakan aplikasi khusus regresi linier berganda di- mana dalam persamaan regresinya mengandung unsur interaksi yang didapat dari selisih mutlak dari variabel independen (Ghozali, 2005). Model persamaan regresi diformulasikan sebagai berikut :
$\mathrm{PTK}=\alpha+\beta_{1} \mathrm{P}+\beta_{2} \mathrm{PK}+\beta_{3} \mathrm{LoC}+\beta_{4} \mathrm{SE}+$ $\beta_{5} \mathrm{TBE}+\beta_{6} \mathrm{P} * \mathrm{TBE}+\beta_{7} \mathrm{PK}$ TBE + $\beta_{8} \mathrm{LOC} * \mathrm{TBE}+\beta_{9} \mathrm{SE} * \mathrm{TBE}+\mathrm{e}$.

PTK adalah perilaku auditor pemerintah daerah menghadapi tekanan kerja. $\mathrm{P}$ adalah pendidikan. PK adalah pengalaman kerja. LoC adalah locus of control. SE adalah self efficacy. TBE adalah tuntutan bersikap etis. $\mathrm{P} * \mathrm{TBE}$ adalah interaksi pendidikan dan tuntutan bersikap etis. PK*TBE adalah interaksi pengalaman kerja dantuntutan bersikap etis. LoC*TBE adalah interaksi locus of control dan tuntutan bersikap etis. SE*TBE adalah interaksi selfefficacy dan tuntutan bersikap etis. E adalah error

\section{ANALISIS DAN PEMBAHASAN}

Kuesioner penelitian yang disebarkan kepada responden sejumlah 164, dapat digunakan untuk analisis adalah sebanyak 147 sehingga menghasilkan response rate $89,63 \%$. Secara detail sampel dalam penelitian ini disajikan dalam Tabel 1 . Demografi responden tersaji dalam Tabel 2, 3, 4, dan 5 .

Selanjutnya atas jawaban dari responden dilakukan uji validitas dan reliabilitas dengan software SPSS versi 17.0 dimana didapatkan bahwa seluruh item/ indikator yang dimintakan tanggapan adalah valid dan kuesioner adalah reliabel. Tahapan berikutnya adalah uji asumsi klasik dimana hasil menunjukkan bahwa data dalam penelitian ini berdistribusi

Tabel 1.

Jumlah Sampel

\begin{tabular}{lccc}
\hline \multicolumn{1}{c}{ Kuesioner } & $\begin{array}{c}\text { Jum } \\
\text { lah }\end{array}$ & Satuan & $\begin{array}{c}\text { Prosen } \\
\text { tase(\%) }\end{array}$ \\
\hline Disebarkan & 164 & Eksemplar & 100,00 \\
$\begin{array}{l}\text { Kembali } \\
\text { Tidak terisi }\end{array}$ & 152 & Eksemplar & 92,68 \\
$\begin{array}{l}\text { dengan } \\
\text { lengkap }\end{array}$ & 5 & Eksemplar & 3,04 \\
$\begin{array}{l}\text { Digunakan } \\
\text { untuk analisa } \\
\text { data }\end{array}$ & 147 & Eksemplar & 89,63 \\
\hline
\end{tabular}


normal, tidak terjadi multikolinearitas, dan tidak terdapat heteroskedastisitas. Hasil uji regresi linier berganda MRA disajikan pada Tabel 6.

Interaksi pendidikan dan tuntutan bersikap etis terhadap perilaku auditor dalam menghadapi tekanan kerja.

Tabel 6 memperlihatkan hasil pengujian hipotesis bahwa interaksi pendidikan dan tuntutan bersikap etis memiliki pengaruh positif dan signifikan terhadap perilaku auditor dalam menghadapi tekanan kerja, sehingga $\mathrm{H} 1$ dapat dibuktikan oleh data penelitian. Didukungnya Hipotesis 1 mengindikasikan bahwa peningkatan interaksi pendidikan dan tuntutan bersikap etis akan mengakibatkan perilaku auditor lebih baik dalam menghadapi tekanan

Tabel 2.

Jenjang Jabatan dan Kedudukan dalam Tim

\begin{tabular}{lccc}
\hline \multicolumn{1}{c}{ Uraian } & $\begin{array}{c}\text { Jum } \\
\text { lah }\end{array}$ & $\begin{array}{c}\text { Satu- } \\
\text { an }\end{array}$ & $\begin{array}{c}\text { Prosent } \\
\text { ase (\%) }\end{array}$ \\
\hline Jabatan & & & \\
PFA & 91 & orang & 61,90 \\
P2UPD & 56 & orang & 38,10 \\
Total & $\mathbf{1 4 7}$ & orang & $\mathbf{1 0 0 , 0 0}$ \\
Kedudukan da- & & & \\
lam Tim & & & \\
Pengendali Mu- & 0 & orang & 0,00 \\
tu & & & \\
Pengendali & 9 & orang & 6,12 \\
Teknis & 46 & orang & 31,29 \\
Ketua Tim & 46 & orang & 62,59 \\
Anggota Tim & 92 & $\mathbf{1 0 0 , 0 0}$ \\
Total & $\mathbf{1 4 7}$ & orang & $\mathbf{1 0 0}$ \\
\hline
\end{tabular}

Tabel 3.

Jenis Kelamin

\begin{tabular}{lrcr}
\hline \multicolumn{1}{c}{ Uraian } & Jumlah & Satuan & $\begin{array}{r}\text { Prosen- } \\
\text { tase (\%) }\end{array}$ \\
\hline Laki-laki & 55 & orang & 37,41 \\
Perempuan & 92 & orang & 62,59 \\
Total & $\mathbf{1 4 7}$ & orang & $\mathbf{1 0 0 , 0 0}$ \\
\hline
\end{tabular}

Tabel 4.

Pengalaman Kerja

\begin{tabular}{lccc}
\hline \multicolumn{1}{c}{ Uraian } & $\begin{array}{c}\text { Jum } \\
\text { lah }\end{array}$ & Satuan & $\begin{array}{c}\text { Prosent } \\
\text { ase (\%) }\end{array}$ \\
\hline $\begin{array}{l}\text { Belum Berpen- } \\
\text { galaman }\end{array}$ & 23 & orang & 15,64 \\
$\begin{array}{l}\text { Sudah Berpen- } \\
\text { galaman }\end{array}$ & 124 & orang & 84,36 \\
Total & $\mathbf{1 4 7}$ & orang & $\mathbf{1 0 0 , 0 0}$ \\
\hline
\end{tabular}

kerja. Semakin tinggi tingkat pendidikan auditor ketika didukung dengan dorongan untuk bersikap etis melalui konsistensi penerapan standar etika profesi oleh instansi menyebabkan perilaku auditor ketika menghadapi tekanan kerja menjadi lebih etis atau menolak berperilaku disfungsional.

Hasil penelitian ini sejalan dengan Pierce dan Sweeny (2000); Keller et al. (2007); Kum-Lung dan Teck-Chai (2010) yang menyatakan bahwa faktor pendidikan sangat bertalian dengan sikap atau perilaku etis dan penerimaan terhadap budaya etis. Hasil penelitian ini juga memberikan tambahan penegasan temuan yang menyatakan penguatan faktor pendidikan dengan pertimbangan etis dapat mendorong seorang auditor untuk menolak berperilaku disfungsional (Hidayat \& Handayani, 2010), yaitu bahwa pertimbangan etis oleh individu auditor tersebut harus didorong melalui penerapan

Tabel 5.

Pendidikan

\begin{tabular}{lccc}
\hline \multicolumn{1}{c}{ Uraian } & $\begin{array}{c}\text { Jum } \\
\text { lah }\end{array}$ & $\begin{array}{c}\text { Satu- } \\
\text { an }\end{array}$ & $\begin{array}{c}\text { Prosen- } \\
\text { tase (\%) }\end{array}$ \\
\hline Formal & & & \\
D IV / S1 & 66 & orang & 44,90 \\
S1 + PPA & 26 & orang & 17,69 \\
S2 & 51 & orang & 34,69 \\
PPA + S2 & 4 & orang & 2,72 \\
S3 & 0 & orang & 0,00 \\
Total & $\mathbf{1 4 7}$ & orang & $\mathbf{1 0 0 , 0 0}$ \\
Keprofesian & & & \\
Wajib & & & \\
Belum pernah & 0 & orang & 0,00 \\
Pembentukan & 91 & orang & 61,91 \\
Ketua Tim & 47 & orang & 31,97 \\
Dalnis & 9 & orang & 6,12 \\
Daltu & 0 & orang & 0,00 \\
Total & $\mathbf{1 4 7}$ & orang & $\mathbf{1 0 0 , 0 0}$ \\
Pelatihan & & & \\
Pengembangan & & & \\
Belum pernah & 2 & orang & 1,36 \\
Pernah & 25 & orang & 17,00 \\
Jarang & 68 & orang & 46,27 \\
Sering & 50 & orang & 34,01 \\
Sangat sering & 2 & orang & 1,36 \\
Total & $\mathbf{1 4 7}$ & orang & $\mathbf{1 0 0 , 0 0}$ \\
\hline
\end{tabular}


standar etika profesi oleh instansi. Hal ini sesuai saran Chan dan Leung (2006) bahwa intervensi etika oleh instansi penting dalam membuat auditor lebih mempertimbangkan etika dalam perilakunya.

Interaksi pengalaman kerja dan tuntutan bersikap etis terhadap perilaku auditor dalam menghadapi tekanan kerja.

Tabel 6 memperlihatkan hasil pengujian hipotesis bahwa interaksi pengalaman kerja dan tuntutan bersikap etis memiliki pengaruh positif dan signifikan terhadap perilaku auditor dalam menghadapi tekanan kerja, sehingga H2 didukung data penelitian. Didukungnya Hipotesis 2 mengindikasikan bahwa semakin meningkatnya interaksi pengalaman kerja dan tuntutan bersikap etis menyebabkan perilaku auditor akan semakin baik dalam menghadapi tekanan kerja. Semakin berpengalaman seorang auditor ketika didukung dengan dorongan untuk bersikap etis melalui konsistensi penerapan standar etika profesi oleh instansi menyebabkan perilaku auditor ketika menghadapi tekanan kerja menjadi lebih etis atau menolak berperilaku disfungsional.

Temuan ini sejalan dengan temuan Pierce dan Sweeny (2000); Johnstone et al. (2002); O'Leary dan Stewart (2007); Ghazali dan Ismail (2013) yang menemukan bahwa penerimaan terhadap budaya etis oleh individu akan meningkat seiring pengalaman kerjanya yang bertambah, sehingga dapat menolak perilaku disfungsional. Saran Chan dan Leung (2006) bahwa intervensi etika oleh instansi penting dalam membuat auditor lebih mempertimbangkan etika dalam perilakunya juga mendapatkan dukungan melalui hasil penelitian ini.

\section{Interaksi locus of control dan tuntutan bersikap etis terhadap perilaku auditor dalam menghadapi tekanan kerja.}

Hasil statistik seperti tampak dalam Tabel 6 menunjukkan bahwa pengaruh interaksi locus of control dan tuntutan bersikap etis tidak cukup signifikan terhadap perilaku auditor dalam menghadapi tekanan kerja, sehingga H3 tidak cukup didukung data penelitian. Namun demikian, positifnya arah koefisien mengindikasikan bahwa semakin tinggi interaksi locus of control dan tuntutan bersikap etis cukup mendorong perilaku auditor dalam menghadapi tekanan kerja semakin baik. Locus of control yang semakin baik atau internal, ketika didukung dengan dorongan untuk bersikap etis melalui konsistensi penerapan standar etika profesi oleh instansi, ternyata dapat cukup mengarahkan perilaku auditor yang menghadapi tekanan kerja menjadi lebih etis atau menolak per-

Tabel 6.

Hasil Analisis Regresi Linier Berganda MRA

\begin{tabular}{|c|c|c|c|c|c|}
\hline \multirow[t]{2}{*}{ Variabel } & \multicolumn{2}{|c|}{ Unstandardized Coefficients } & \multirow{2}{*}{$\begin{array}{c}\begin{array}{c}\text { Standardized } \\
\text { Coefficients }\end{array} \\
\text { Beta } \\
\end{array}$} & \multirow[t]{2}{*}{$\mathbf{T}$} & \multirow[t]{2}{*}{ Sig. } \\
\hline & B & Std. Error & & & \\
\hline (Constant) & 160.352 & 26.802 & & 5.983 & .000 \\
\hline $\mathrm{P}$ & -8.743 & 3.484 & -1.093 & -2.509 & .013 \\
\hline PK & -6.775 & 4.394 & -.324 & -1.542 & .125 \\
\hline LoC & -.935 & .643 & -.713 & -1.454 & .148 \\
\hline SE & -1.395 & 1.384 & -.592 & -1.008 & .315 \\
\hline TBE & -6.663 & 1.610 & -2.306 & -4.139 & .000 \\
\hline $\mathrm{P} * \mathrm{TBE}$ & .427 & .203 & .923 & 2.098 & $.038 *$ \\
\hline $\mathrm{PK} * \mathrm{TBE}$ & .607 & .256 & .540 & 2.368 & $.019 *$ \\
\hline LoC*TBE & .068 & .037 & 1.906 & 1.806 & .073 \\
\hline $\mathrm{SE} * \mathrm{TBE}$ & .138 & .082 & 1.288 & 1.676 & .096 \\
\hline Adjusted $\mathrm{R}^{2}$ & 0.478 & & & & \\
\hline F-statistic & 15.878 & & & & \\
\hline Prob (F-statistic) & 0.000 & & & & \\
\hline
\end{tabular}


ilaku disfungsional.

Temuan ini masih mendukung hasil penelitian-penelitian sebelumnya, diantaranya oleh Nasution dan Ostermark (2012); Dali dan Mas'ud (2014); serta Muawanah dan Indriantoro (2001) bahwa locus of control berpengaruh terhadap judgment auditor dengan kesadaran etisnya. Tidak cukup signifikannya pengaruh interaksi locus of control dan tuntutan bersikap etis dalam penelitian ini dimungkinkan terjadi karena locus of control yang baik atau tipe internal adalah keyakinan seseorang yang kuat bahwa penentu nasibnya adalah dirinya sendiri dan dirinya pantas mendapatkan penghargaan yang sepadan atas prestasinya. Dengan demikian, selain dorongan melalui konsistensi penerapan standar etika, perilaku yang diharapkan dari seorang auditor pemerintah daerah juga harus didukung dengan pemberian penghargaan yang layak atas capaian kinerja atau prestasinya.

Interaksi self-efficacy dan tuntutan bersikap etis terhadap perilaku auditor dalam menghadapi tekanan kerja.

Uji statistik dalam Tabel 6 menunjukkan bahwa pengaruh interaksi self-efficacy dan tuntutan bersikap etis tidak cukup signifikan terhadap perilaku auditor dalam menghadapi tekanan kerja, sehingga $\mathrm{H} 4$ tidak cukup didukung data penelitian. Namun demikian, positifnya arah koefisien mengindikasikan bahwa semakin tinggi interaksi self-efficacy dan tuntutan bersikap etis cukup mendorong perilaku auditor dalam menghadapi tekanan kerja semakin baik. Self-efficacy yang semakin baik atau perasaan semakin mampu untuk menyelesaikan tugas audit, ketika didukung dengan dorongan untuk bersikap etis melalui konsistensi penerapan standar etika profesi oleh instansi, ternyata dapat cukup mengarahkan perilaku auditor yang menghadapi tekanan kerja menjadi lebih etis atau menolak perilaku disfungsional.

Temuan penelitian ini dapat memperkuat temuan Iskandar et al. (2010) yang menyatakan bahwa individu dengan self-efficacy tinggi pada situasi tertentu akan mencurahkan semua usaha dan perhatiannya sesuai dengan tuntutan situasi tersebut dalam mencapai tujuan dan kinerja yang telah ditentukan. Tidak cukup signifikannya pengaruh interaksi self -efficacy dan tuntutan bersikap etis terhadap perilaku auditor dalam menghadapi tekanan kerja dimungkinkan terjadi karena self-efficacy hanya terkait dengan perasaan merasa mampu dan bukan kemampuan itu sendiri.

\section{SIMPULAN}

Kesimpulan yang dapat ditarik dari penelitian ini adalah bahwa berdasarkan statistik ditemukan bahwa ketika diinteraksikan dengan tuntutan bersikap etis, faktor personal yang berpengaruh terhadap perilaku auditor pemerintah daerah adalah pendidikan dan pengalaman kerja. Sedangkan interaksi locus of control dan self-efficacy dengan tuntutan etis tidak cukup mampu mempengaruhi perilaku auditor dalam menghadapi tekanan kerja. Hasil ini mengindikasikan bahwa penguatan faktor pendidikan dan pengalaman kerja auditor yang didukung dengan konsistensi penerapan standar etika profesi oleh instansi dapat mendorong pada peningkatan kualitas audit yang sangat diharapkan menjadi produk dari Aparat Pengawasan Internal Pemerintah (APIP).

\section{KETERBATASAN DAN SARAN}

Penelitian ini mengandung keterbatasan sehingga perlu kehati-hatian dalam menggeneralisir hasilnya. Keterbatasan penelitian ini adalah bahwa hasil penelitian semata-mata mendasarkan pada hasil pengolahan data yang didapatkan dari tanggapan kuesioner yang dikirimkan. Metode ini mengandung kelemahan karena berupa self-report dan kurang bisa mengungkap kedalaman pemahaman dan respon dari responden. Sehubungan hal tersebut disarankan pada penelitian selanjutnya selain digunakan kuesioner juga dilakukan metode wawancara baik kepada auditor maupun kepada pihakpihak yang terkait yaitu atasan dan auditee.

\section{DAFTAR PUSTAKA}

Acevedo, D.M.L. (2007). Audit quality: an Analysis of management, auditor, and environment factors (Disertasi). Uni- 
versity of Arkansas, USA.

Carpenter, B.W., \& Mahoney, D.P. (2001). Improving the audit process: the final report of the panel on audit effectiveness. The National Public Accountant, 46(5), 15-44.

Chan, S.Y.S., \& Leung, P. (2006). The effects of accounting students' ethical reasoning and personal factors on their ethical sensitivity. Managerial Auditing Journal, 21(4), 436-457.

Chen, J.C., Silverthorne, C., \& Hung, J. (2006). Organization communication, job stress, organizational commitment, and job performance of accounting professionals in Taiwan and America. Leadership and Organization Development Journal, 27(4), 242-249.

Christiawan, Y.J. (2002). Kompetensi dan independensi akuntan publik: refleksi hasil penelitian empiris. Jurnal Akuntansi dan Keuangan, 4(2), 79-92.

Comunale, C.L., \& Sexton, T.R. (2004). Credibility in the internal audit function. Internal Auditing, 19(1), 10-16.

Cort, K.T., Griffith, D.A. \& White, D.S. (2007). An attribution theory approach for understanding the internationalization of professional service firms. International Marketing Review, 24(1), 9-25.

Dali, N., \& Mas'ud, A. (2014). The impact of professionalism, locus of control, and job satisfaction on auditors' performance: Indonesia evidence. International Journal of Business and Management Invension, 3(10), 63-73.

Donnelly, D.P., Quirin, J.J., \& O’Bryan, D. (2003). Attitudes toward dysfunctional audit behavior: The effects of locus of control, organizational commitment, and position. The Journal of Applied Business Research, 19(1), 95-108.

Engko, C. (2006). Pengaruh kepuasan kerja terhadap kinerja individual dengan self esteem dan self efficacy sebagai variabel moderating. Paper dipresentasikan pada Simposium Nasional Akuntansi IX, Padang.

Ghazali, N.A.M., \& Ismail, S. (2013). The influence of personal attributes and organizational ethics position on accountants' judgments: Malaysian scenario. Social Responsibility Journal, 9(2), 281-297.

Ghozali, I. (2005). Analisis Multivariate dengan Program SPSS (Edisi ketiga). Semarang: Badan Penerbit Universitas Diponegoro.
Gibson, J.L., Ivancevich, J.M. \& Donnelly, J.H. (2000), Organizations : Behavior, structure, processes. Boston, MA: McGraw-Hill. Terjemahan Nunuk Adiarni. (2000). Organisasi : Struktur, proses, perilaku (Jilid 1). Jakarta: Binarupa Aksara.

Gramling, A., \& Hermanson, D.R. (2006). What role is your internal audit function playing in corporate governance? Internal Auditing, 21(6), 37-39.

Handayani, W. (2008). Dampak komitmen organisasi, self efficacy terhadap konflik peran dan kinerja karyawati PT. HM Sampoerna Tbk. di Surabaya. Jurnal Riset Ekonomi dan Bisnis, 8(2), 70-78.

Herliansyah, Y., \& Ilyas, M. (2006). Pengaruh pengalaman auditor terhadap penggunaan bukti tidak relevan dalam auditor judgement. Paper dipresentasikan pada Simposium Nasional Akuntansi IX, Padang.

Hidayat, W., \& Handayani, S. (2010). Peran Faktor-faktor individual dan pertimbangan etis terhadap perilaku auditor dalam situasi konflik audit pada lingkungan inspektorat Sulawesi Tenggara. Jurnal Mitra Ekonomi dan Manajemen Bisnis, 1(1), 83-112.

Ikhsan, A. (2008). Metode penelitian akuntansi keperilakuan (Edisi pertama). Yogyakarta: Graha Ilmu.

Iskandar, T.M., Sari, R.N., Sanusi, Z. M. \& Anugerah, R. (2012). Enhancing auditors' performance. Managerial Auditing Journal, 27(5), 462-476.

Jamilah, S., Fanani, Z. \& Chandrarin, G. (2007). Pengaruh gender, ketaatan, dan kompleksitas tugas terhadap audit judgement. Paper dipresentasikan pada Simposium Nasional Akuntansi $\mathrm{X}$, Makassar.

Johnstone, K.M., Bedard, J.C., \& Biggs, S.F. (2002). Aggressive client reporting: Factors affecting auditors' generation of financial reporting alternatives. Auditing: Journal of Practice and Theory, 21(1), 47-65.

Kell, W.G., Johnson, R.N., \& Boynton, W.C. (2002). Modern auditing (Edisi ketujuh). Jakarta: Penerbit Erlangga.

Keller, A.C., Smith, K.T., \& Smith, M. (2007). Do gender, educational level, religiosity, and work experience affect the ethical decision-making of U.S. accountant? Critical Perspective on Accounting, 18, 299-314.

Kum-Lung, C., \& Teck-Chai, L. (2010). 
Attitude towards busness ethics: Examining the influence of religiosity, gender, and education level. International Journal of Marketing Studies, 2(1), 225-232.

Lord, A.T. \& DeZoort, F.T. (2001). The impact of commitment and moral reasoning on auditors' responses to social influence pressure. Accounting, Organizations and Society, 26, 215235.

Luthans, F. (2006). Organizational behavior (Edisi kesepuluh). Singapore: McGraw Hill. Terjemahan Vivin, Andika, Yuwono. (2006). Perilaku organisasi (Edisi kesepuluh). Yogyakarta: Penerbit Andi.

Muawanah, U., \& Indriantoro, N. (2001). Perilaku akuntan publik dalam situasi konflik audit: peran locus of control , komitmen profesi dan kesadaran etis. Jurnal Riset Akuntansi Indonesia, 4, 133-147.

Nasution, D., \& Ostermark, R. (2012). The impact of social pressures, locus of control, and professional commitment on auditors' judgement. Indonesian evidence. Asian Review of Accounting, 20(2), 163-178.

Nather, F. (2013). Exploring the impact of formal education on the moral reasoning abilities of college students. College Student Journal, 47 (3), 470-477.

O'Leary, C. \& Stewart, J. (2007). Governance factors affecting internal auditor' ethical decision making. Managerial Auditing Journal, 22(8), 787-808.

Paino, H., Ismail, Z., \& Smith, M. (2011). Dysfunctional audit behaviour: The effects of employee performance, turnover intentions and locus of control. Journal of Modern Accounting and Auditing, 7(4), 418-423.

Peraturan Menteri Dalam Negeri Nomor 47 Tahun 2010. Petunjuk teknis jabatan fungsional pengawas penyelenggaraan urusan pemerintahan di daerah dan angka kreditnya. 9 Maret 2010. Berita Negara Republik Indonesia Tahun 2010 Nomor 438. Jakarta

Peraturan Menteri Pendayagunaan Aparatur Negara No. PER/04/M.PAN/03/2008. Kode etik aparat pengawasan internal pemerintah. Kementrian Pendayagunaan Aparatur Negara. Jakarta

Peraturan Menteri Pendayagunaan Aparatur Negara No. PER/220/M.PAN/7/2008. Jabatan fungsional auditor dan angka kreditnya. Kementrian Pendayagunaan Aparatur Negara. Jakarta

Peraturan Pemerintah Nomor 40 Tahun 2010. Perubahan atas peraturan pemerintah nomor 16 tahun 1994 tentang jabatan fungsional pegawai negeri sipil. 1 Maret 2010. Lembaran Negara Republik Indonesia Tahun 2010 Nomor 5121. Jakarta

Peterson, D.K. (2003). The relationship between ethical pressure, relativistic moral beliefs and organizational commitment. Journal of management Psychology, 557-572.

Peytcheva, M., \& Gillett, P.R. (2012). Auditor perceptions of prior involvement and reputation threats as antecedents of quality threatening audit behavior. Managerial Auditing Journal, 27(9), 796-820.

Pierce, B., \& Sweeney, B. (2010). The relationship between demographic variables and ethical decision making of trainee accountants. International Journal of Auditing, 14(1), 79-99.

Pratiwi, M.G., \& Suwardi, E. (2007). Pengaruh locus of control, tingkat pendidikan, pengalaman kerja, dan pertimbangan etis terhadap perilaku auditor dalam situasi konflik audit karena tekanan atasan dan auditee pada BPK RI perwakilan Yogyakarta dan Surabaya (Tesis). Universitas Gadjah Mada, Yogyakarta.

Purnamasari, P., Rohman. A., \& Chariri, A. (2014). Determinant factors of cognitive moral development in audit activities : Ethical decision perspective (Empirical study on public accounting firms). International Journal of Research in Business and Technology, 5(2), 609616.

Puspitaningtyas, Z. (2007). Pemanfaatan informasi akuntansi bagi investor dalam proses pengambilan keputusan investasi. Jurnal NeO-Bis, 1(2), 121-129.

Rai, A. (2008). Audit kinerja pada sektor publik. Jakarta: Penerbit Salemba Empat.

Reiss, M.C., \& Mitra, K. (1998). The effect of individual difference factors on the acceptability ofethical and unethical workplace behaviors. Journal of Business Ethics, 17, 158-159.

Robbins, S. P. (2003). Organizational behavior (Edisi kesepuluh). New Jersey: Prentice Hall International Inc.

Robbins, S.P., \& Judge, T.A. (2008). Perilaku organisasi (Edisi keduabelas). 
Jakarta: Penerbit Salemba Empat.

Robertson, J.C. (2007). Staff auditor reporting decisions under time deadline pressure. Managerial Auditing Journal, 22(4), 340-353.

Sanusi, Z.M. \& Iskandar, T.M. (2007). Audit judgment performance: Assessing the effect of performance incentives, effort and task complexity. Managerial Auditing Journal, 22(1), 34-52.

Schneider, A. (2003). An examination of whether incentive compensation and stock ownership affect internal auditor objectivity. Journal of Management Issues, 15(4), 486-497.

Sekaran, U., \& Bougie, R. (2013). Research method for business, a skill building ppproach (Edisi keenam). New York : John Wiley \& Sons Inc.

Setyaningrum, D. (2012). Analisis faktorfaktor yang mempengaruhi kualitas audit BPK RI. Paper dipresentasikan pada Simposium Nasional Akuntansi $\mathrm{XV}$, Banjarmasin.

Shahri, M., Abdoli, M. \& Rahmani, M. (2013). Ethical perceptions of earning management: the effect of gender and experience. Technical Journal of Engineering and Applied Sciences, 3 (19), 2426-2430.

Shafer, W.E. (2002). Ethical pressure, organizational-professional conflict, and related work outcomes among management accountants. Journal of Business Ethics, 38(3), 263-275.

Shafer, W.E., Morris, R.E., \& Ketchand, A.A. (2001). Effects of personal values on auditors'ethical decisions. Accounting, Auditing \& Accountability Journal, 14(3), 254-277.

Shapeero, M., Koh, H.C. dan Killough. L.N. (2003). Under-reporting and premature sign-off in public accounting firm. Managerial Accounting Journal, 18(6), 478-489.

Svanberg, J., \& Öhman, P. (2013). Auditors' time pressure: does ethical culture support audit quality? Managerial Auditing Journal, 28(7), 572-591.

Tan, H.T., Ng, T.B., \& Mak, B.W. (2002). The effect of task complexity on auditors' performance: the impact of accountability and knowledge. Auditing: $A$ Journal of Practice and Theory, 21(2), 81-95.

Umar, A. \& Anandarajan, A. (2004). Dimensions of pressures faced by auditors and its impact on auditors' independence. Managerial Auditing Journal, 19 (1), 99-116.

Undang-Undang Republik Indonesia Nomor 32 Tahun 2004 tentang Pemerintah daerah. 15 Oktober 2004. Lembaran Negara Republik Indonesia Tahun 2004 Nomor 4437

Wiwoho, L.H. (26 Maret 2015). Inspektorat belum paripurna cegah korupsi, diakse s d a ri ht p:// $\mathrm{n}$ a s i o n a l. k o m p a s. c o m / $\mathrm{read} / 2015 / 03 / 26 / 15000041 /$ I $\mathrm{n}$ spektorat.Belum.Paripurna.Cegah.Kor upsi

Wursanto, I. (2005). Dasar-dasar ilmu organisasi. Yogyakarta: Penerbit Andi.

Yoo, B., \& Donthu, N. (2002). The effects of marketing education and individual cultural values on marketing ethics of students. Journal of Marketing Education, 4(2), 92-103.

Yuen, D.C.Y., Law, P.K., Lu, C. \& Guan, J.Q. (2013). Dysfunctional auditing behaviour: empirical evidence on auditors' behaviour in Macau. International Journal of Accounting \& Information Management, 21(3), 209-226. 